\title{
Environmental Ethics - The Fullest Extension of Human Ethics
}

\author{
Derek S.J. D'Souza ${ }^{1}$, Russell D'Souza² \\ ${ }^{1}$ Director, National Bioethics Curriculum Implementation Centre, MIMER Medical College, Talegaon, \\ Pune. \\ ${ }^{2}$ Director of Education, UNESCO Chair in Bioethics, Haifa .
}

\begin{abstract}
Ethics is defined as a set of moral principles that guide the conduct of both individuals and various social groups and "moral" refers to the ability of humans to judge between right or wrong and good or bad. Environment means 'something that surrounds'. 'Environmental ethics' can be defined as the human attitudes and values that influence individual behavior and government policy toward nature. The study of environmental ethics is to ensure that human actions do not do further damage to the natural world. This is vital if we desire that future generations can live peaceful and prosperous lives in harmony with nature and continue to enjoy all the amenities offered to man by Mother Nature. The obligation rests with each and every one of us today to take the responsibility to save our planet for future generations. We must save and preserve our natural resources in such a way that future generations will be able to live in harmony with nature and enjoy its benefits.
\end{abstract}

Key Words: environment, ethics, environment ethics, morals.

\section{INTRODUCTION}

"Ethics" may be defined as a set of moral principles that guide the conduct of both individuals and various social groups. The word "moral" refers to the ability of humans to judge between right or wrong and good or bad. Moral principles of an individual are shaped by exposure to a multitude of human behavior and value systems during their formative years. These are internalized by an individual through his/her personal growth and self-realization and the continued socialization process. The set of values in a society specify certain duties and obligations, norms and permissions; of what is considered acceptable and what is regarded as noacceptable behavior.

Environment means 'something that surrounds'. This includes all our surroundings both natural and man-made elements. However, when we consider the term 'environmental ethics', we usually refer to the non-human natural environment. 'Environmental ethics' can be defined as the human attitudes and values that influence individual behavior and government policy toward nature ${ }^{1}$

In other words, environmental ethics may be understood as the logical interpretation of the relationship between human beings and their natural environment. The study of environmental ethics is to ensure that human actions do not do further damage to the natural world. This is vital 
if we desire that future generations can live peaceful and prosperous lives in harmony with nature and continue to enjoy all the amenities offered to man by Mother Nature.

Environmental ethics is normally divided into can be divided into two categories: (1) anthropocentric and (2) non-anthropocentric.

Anthropocentric environmental ethics considers the non-human natural world as a whole to a means that serves human ends [1]. It assumes that only human beings have moral value. Thus, although humans have responsibilities regarding the natural environment, they do not have direct responsibilities to the natural world [2]. Therefore, it can also be regarded as ethics "of human beings for the use of the environment".

Non-anthropocentric environmental ethics, in contrast, assumes that both humans and nonhumans have mutual and intrinsic value to each other. We understand the dependence of all livings things on plants, which are the true autotrophs as they make their own food. All other animals are dependent on plants or other smaller animals which are considered as part of the food chain. Humans therefore, have responsibilities towards their own species, as well as to all other non-human entities of the natural world [3].

\section{Characteristics of Environmental Ethics [4]}

\section{Firstly, environmental ethics is extended}

Environmental ethics extends beyond the immediate community, state or even the nation to include not only all people everywhere, as well as animals and the whole of nature - the biosphere - both now and beyond the imminent future to include future generations.

\section{Secondly, environmental ethics is interdisciplinary}

The field of environmental ethics involves various inter-related subjects and areas of consensus such as ethics, political sciences, environmental economics, environment sciences and ecosciences, for example. Each of these fields offers distinctive perspectives and approaches to the field of environmental ethics, and in turn environmental ethics offers important fundamental knowledge for these disciplines. Hence it is important that in order to solve many of the problems we face today, all issues are considered with an interdisciplinary approach.

\section{Third, environmental ethics is plural}

As discussed, environmental ethics is a discipline where myriad ideas and contrasting perceptions vie for importance and implementation. Each specific subject provides unique and, in some sense, reasonable ethical justifications for environmental protection. The approaches may be different, but the ultimate goals are similar, and the consensus is that it is everyone's duty to protect the environment. As envisaged from an Indian standpoint we find that the basic concepts of environmental ethics and protection are embodied in many of our rich and varied cultural traditions. This pluralism of philosophies and multiethnic perceptions is critical for environmental ethics to retain its vitality.

\section{Fourth, environmental ethics is global}

It is well established fact that environmental pollution does not respect state or national boundaries and so no country should be burdened to contend with this problem alone. The global ecological crisis is a reality that we all have to address with solidarity to have any hope of success. People everywhere must reach a consensus and cooperate at the personal, national, regional, multinational and global levels in order to win the battle against the global environmental crisis.

\section{Fifth, environmental ethics is revolutionary}

A revolution is required in order to battle this crisis and find a way to rectify the mess that the world finds itself in. Environmental ethics requires us to challenge the dominant and deep-rooted anthropocentrism of generations and understand that our duty extends to future generations and all living beings that co-exist on the planet. We must understand that we are responsible for what condition we leave this planet for future generations. 


\section{Sustainable Development}

Policy makers and planners are united on the subject that rather than talk of development alone what we need to plan for is 'sustainable development'. Sustainable development necessitates that equilibrium is maintained by finding common ground between socioeconomic and environmental needs. It can be defined as: "A continuing process of mediation among social, economic and environmental needs, which results in positive socioeconomic change that does not undermine the ecological and social systems upon which communities and society are dependent. Its successful implementation requires integrated policy, planning, and social learning processes; its political viability depends on the full support of the people it affects through their governments, their social institutions, and their private activities" [5].

It is evident that each and every member of the society (which aspires to implement the ideals of sustainable development), and individual members to uphold environment-friendly practices if the goals of sustainable development are to be attained. Sustainable development encourages productive activities which would maximize social welfare but would not contribute to the depletion of the resource base for future generations; it requires that development planning follow the principle of minimizing wastage, minimizing generation of pollution, and maximizing recycling. It is mandatory that, development policy strategists, planning commissions, and even the recipients of the planning outcomes all follow strict ethical norms and commit towards protecting the environment. It is vital to inculcate good environment friendly practices into the daily habits and practices of the society, in order that the goal of sustainable development is achieved.

\section{Ethics and sustainable development}

Ethics identified by Murcott [6] as compatible with sustainable living are:

(1) To refrain from killing;

(2) To treat and value all natural and cultural systems that support us as possessors of their own intrinsic value;

(3) To consume only to such extent that is necessary to meet one's basic needs. Any surplus should be used for the purpose of ensuring justice and equity for the current generation as well as for generations to come;

(4) Keeping in mind that humans and nature cannot be separated, "nature", should be studied with "a deep sense of humility and wonder and the tools of science and technology must be used for the well-being of humans and nature"

\section{Finding solutions to environmental issues}

One of the major means by which solutions can be found is through the inculcation of environmental ethics from the earliest stages and ensuring that it becomes part and parcel of all daily activities and social behaviour. Just as a child grows up in society learning what is good and bad, right and wrong - similarly good environmental ethical practices need to be introduced and reinforced at all levels $[7,8,9]$.

\section{Charity begins at home}

When a child is exposed to the concepts of "right" and "wrong", it is vital that a child is made aware of the right ways he/she should interact with the environment. In this way it is possible to instil a sense of environmental ethics that will make an individual behave and act in environment friendly ways, from the very early stages of his/her life. If a child is brought up in a house where the parents and elder siblings care about trees and plants, avoid the wastage of water, follow the habit of recycling, etc, the child will follow these same practices for a lifetime. Parents should teach their children how critical the environment is for all of us, and the importance of protecting the environment always.

\section{Power of peers}

After the family the next crucial social stage is the peer group of the child, young adult and adult as well. Finding the approval of peer group is a major motivating factor in defining an 
individual's social behaviour. If any one member of a peer group acts in an environmental friendly manner, others are also inspired. Thus even if one member of the peer group is environmentally conscious and is able to motivate the others in the group, soon all the other members are likely to exhibit environmentally favourable behaviour.

\section{Cleanliness is next to Godliness}

Religion is an important part of any social foundation and forms the core of the value structure of an individual. Almost all religions emphasize that the environment is an invaluable part of God's creation, and all humans have a obligation to preserve it. The relationship between all the creations of God must be based on justice and equity. Ideal living is to live in harmony with nature and preserve the environment so that it remains the same for future generations to enjoy and appreciate the marvellous creations of nature. All religions can utilise their inherent ability to motivate and mobilize large numbers of society to carry out drives to clean up the environment and also to sustain living habits that are ecologically and environmentally friendly. Religious customs such as bursting of firecrackers, immersion of idols into water bodies that harm the environment also need to be curbed through education and finding environmentally friendly alternatives.

\section{Providing holistic education}

Schools and colleges are other social institutions which play an important role in character development and habit formation into an individual. Many additional moral values, beyond what is taught in a family, can be learned in an educational institution. The most important aspect is that a student looks up to his/her teacher as a role model, and therefore abides with the teachers' instructions more zealously than directions given by parents. The school curriculum can be revised to include topics related to environmental issues and concerns. This will bring about awareness in them to incorporate environmental friendly behaviour and planning. In turn they should also educate others on which practices should be followed and what are the practices that cause harm to society.

It is pertinent to ensure that not only should information be shared but along with that practical examples and alternatives should be made available - for example just telling slum dwellers not to use firewood for cooking is not going to benefit anyone unless alternatives such as 'smokeless chulas' or 'green stoves' are provided to them. The cost involved in buying these 'green' alternatives will be paid back to the society by virtue of the cleaner air for all.

\section{Getting the message across}

In the modern world, mass media, various social networking sites and instant messaging applications on smartphones are ensuring that information can easily and efficiently be disseminated literally all across the globe almost instantaneously. As most of these have the capability of sending text, photos and video - the reach of such technology is actually limitless. Environmental issues can be disseminated to the people in a manner, which appeals to them. Celebrities too can also be used to spread the messages regarding good ecological practices and following an environmentally friendly life-style [10].

\section{Towards a 'greener cleaner' environment}

It is important to understand that each and every one of us should be 'careful' of all our deeds and actions. Many of the small innocent things we do- actually cause greater harm when done in large numbers. Not switching off the engine at long signals and traffic snarls seems innocent but adds greatly to the levels of atmospheric pollution. Similarly setting off firecrackers or unnecessary waste of water, electricity and all natural resources by a large number of 'careless individuals' all adds up to an ever-worsening situation. What is worse is that very often these are the actions of the educated and economically privileged classes. Simply banning things or increasing taxes to discourage emissions has not and will not help. As Einstein once said "We solve our problems using the same thinking as when we created them". 
The obligation rests with each and every one of us today to take the responsibility to save our planet for future generations. We must save and preserve our natural resources in such a way that future generations will be able to live in harmony with nature and enjoy its benefits.

Rigorous and focussed initiatives with practical training in order to preserve our planet should start as early as possible and carry on throughout the educational curriculum. Governments across the globe should empower pollution control authorities with wider and stringent legal powers for punitive action [11]. Technical experts and Captains of industry should be appointed as consultants to clean up and regulate errant industries and sectors. No more can we ignore the situation and believe that it will sort itself out as it is already too late. A mass movement of ethically-driven and committed persons, all across the economic spectrum, is essential for the envisaged changes to be effective. Working together in solidarity towards the common goal of cleaning up the environment is the only way that this monumental problem can be controlled effectively in the years ahead.

\section{REFERENCES}

1. Callicott JB. Environmental philosophy is environmental activism: The most radical and effective kind. Environment Philos Environment Activism 1995;21:100-5.

2. Hatcher T. Environmental ethics as an alternative for evaluation theory in for-profit business contexts. Eval Progr Plann 2004;27(3):357-63.

3. Mitra MN. Ethics for the Use of the Environment vs. Ethics of the Environment. Philos Progress: Vols. XXII-XXIII, 1997,pp.17-32.

4. Yang T. Towards an egalitarian global environmental ethics. Environment Ethics Int Policy 2006;8:23-45.

5. Carley M, Christie I. Managing sustainable development. EarthScan; 2000.

6. Murcott, S. Perspectives in Sustainable Living." Paper presented at the Japan/US Seminar on Sustainable Living and Environmental Ethics, held in Honolulu, Hawaii, 1996.

7. Hardoy JE, Mitlin D, Satterthwaite D. Environmental problems in an urbanizing world: finding solutions in cities in Africa, Asia and Latin America. Routledge; 2013.

8. Gardner GT, Stern PC. Environmental problems and human behavior. Allyn \& Bacon; 1996.

9. Cable S, Cable C. Environmental problems, grassroots solutions. St. Martin's Press; 1994.

10. Foley JA, Ramankutty N, Brauman KA, Cassidy ES, Gerber JS, Johnston M, Mueller ND, O'Connell C, Ray DK, West PC, Balzer C. Solutions for a cultivated planet. Nature 2011;478(7369):337-42.

11. Negev M, Garb Y, Biller R, Sagy G, Tal A. Environmental problems, causes, and solutions: An open question. J Environment Educn 2009;41(2):101-15.

\footnotetext{
$* * * * * * * * * * * * * * * * * * * * * * * * * * * * * * * *$

Acknowledgements - Nil

Source of Funding - Nil

Conflict of Interest $-\mathrm{Nil}$
} 